\title{
腎移植に打ける医学的・社会的課題
}

\author{
大阪大学医学部泌尿器科学教室 \\ 石橋道男園田孝夫
}

\section{MEDICAL AND SOCIAL ISSUES IN KIDNEY TRANSPLANTATION}

\author{
Michio Ishibashi and Takao Sonoda \\ Department of Urology, Osaka University Hospital
}

\section{I.はじめに}

末期腎不全に対する外科的治療としての腎移植がよ り安全により確実に, 高い生存率・生着率がえられる ようになれば，患者からの腎移植への期待はますをす 大きくなるであろう。腎移植成績は，サイクロスポリ ンの導入1)，そして，急性拒絶反応治療薬としてモノク ローナル抗体, muromonab CD3 (Orthoclone OKT3 (B) の臨床応用 ${ }^{233}$ とより向上しており，そのなかでも死 体腎移植成績の向上はめざましい， 1 年生着率は, 血 縁者間生体腎移植と死体腎移植のいずれに打いても約 80〜90\%となっている( ${ }^{4) 5}$. この 1 年目に生着している 症例のらち, 約 $20 \%$ は慢性拒絶反応のため, 2,3 年 後には移植腎機能を喪失し, 血液透析へ再導入となる が, 残りの症例は扮括むね長期の安定した腎機能を維 持し，ほぼ完全な社会復帰が可能となる ${ }^{6}$. このよら に, 比較的安定した治療成績がえられるようになり, 腎移植術そのものは, 一般的な治療技術のひとつに移 行しつつあるといえる。そして，腎移植術は，通常の 医療体制と違って, 藏器の提供者なしにはなりたたな い移植医療としての特殊性をあわせもっている。この 移植医療としての腎移植も, 移植医療のための社会的 条件整備が徐々にす寸みつつあり, 特殊なものから一 般的なむのになる兆しもみられている. 今後, わが国 に扣いてひろく腎移植が移植医療としておこなわれる ためには，ひとつには，拒絶反応をいかに制御し安全 かつ確実に成績があげられるようにするか，そして， 臓器提供をより可能とする医学的・社会的諸条件をい かに整備するか, このふたつのことが, 中心的な課題 となろう。

\section{II. 拒絶反応制御への課題}

サイクロスポリンとOKT3の導入によって, 腎移植
における拒絶反応をより安全により確実に制御するこ とができるようになっているが，まだ，1年目までに 約 $10 \%$ の頻度で制御不可能な拒絶反応があり，その後 の慢性拒絶反応もふくめると全症例の約 3 割は, 現在 の免疫抑制療法によっては制御の不可能なるのとい兄 る(4) . 拒絶反応そのもの ${ }^{778)}$ ，あるいは拒絶反応の治 療910)そのものが, 発症原因とされているサイトメガ ロウイルス (cytomegalovirus, CMV) 感染症は, 致 死的な混合感染や，拒絶反応を誘発し移植腎機能を变 失する原因となるため ${ }^{11121}$ ，拒絶反応の制御にとって 大きな課題となっている。すすなわち，拒絶反応の抑制 法を考兄るらえで，常にCMV 感染症との関係を明ら かにしながら検討することが，必要である.

拒絶反応の機序があきらかになると，それをもとに して新しい免疫抑制療法を臨床に導入する可能性につ ながる，臨床への応用の条件としては，簡便さが必要 である.最近の拒絶反応の機序に関する研究 ${ }^{13)}$ として, 拒絶反応にかかわる免疫担当細胞の細胞膜上の各種抗 原や細胞膜上レセプターに対するモノクローナル抗体 を用いたものが主流となっている。すなわち，種々の 免疫担当細胞に対するモノクローナル抗体を, 移植と 同時に投与することによって, 移植蔵器の生着延長効 果をみて拒絶に関わる免疫担当細胞を確かめる方法が 導入された ${ }^{14) \sim 17) 18)}$ 。この方法は, マウスやラットの移

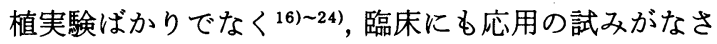
れている2526).そのほかに, サイクロスポリンに代表さ れる免疫抑制剤による免疫抑制作用機序の研究 ${ }^{27)}$, そ して，抗血清や細胞成分の投与による enhancement 導入を用いた古くからの実験的研究は28)29)，いずれも 拒絶反応の機序を明らかにするらえで, 有用な方法と いえる. 移植免度研究に打ける再現性の点から, 動物 
を用いた移植実験では，マウスとラットが主に対象と なる。とくに，ラットを対象とした移植実験は有用で あるが，ラットとヒト相互の共通した免疫現象をとら えてこそ，実験モデルが有効なものとなるので，種間 に抢ける拒絶反応の機序の相異・共通点を常に念頭に おき研究をすすめることが必要である。

拒絶反応と免疫学的活性化指標 ${ }^{2130)}$. 抗原刺激をう け活性化した免度細胞は, 一過性に細胞膜上に, Inter-

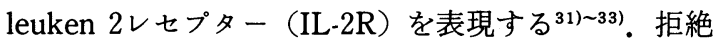
反応の標的となる細胞にくみこまれている主要組織適 合抗原 (Major Histocompatibility Complex, MHC) は, 活性化細胞から分泌されるサイトカインによって 調節をうけ，標的細胞の膜上に新たに表現される ${ }^{34) 35)}$. 拒絶反応時の浸潤細胞中には活性化マクロファージが 存在する ${ }^{2136) ~ 38)}$. そして, 活性化細胞からは, Interleuken 1 (IL-1), IFN- $y$, Tumor Necrosis Factor $(\mathrm{TNF}-\alpha / \beta)$ などの各種サイトカインが分泌され $3^{39 \sim \sim 41)}$. 以上の免疫学的現象は, ラット・マウス移植 実験の検討によって認められた“活性化指標”である.

IL-2R は, 活性化された CD4, CD8各陽性 T 細胞, 一部の B 細胞，マクロファージ，樹状細胞上に表現さ れる ${ }^{32)}$. 活性化された細胞上に表現される IL-2R は, 構造上多様性がみとめられている ${ }^{42)}$. 2 種類の反応基 があり, $55 \mathrm{Kd}(\mathrm{p} 55$ サブニニット, $\beta$-chain) と $75 \mathrm{Kd}(\mathrm{p} 75$ サブニニット， $\alpha$-chain)は, IL-2 親和性は低いか中 等度の強さで結合する，他に，強い親和性をもつとさ れる $\gamma$-chain がある。この IL-2R をるつ細胞は, IL-2 と結合し細胞内にとりこまれ，IL-2依存性の増殖をき たす. 現在, この活性化された細胞上に表現される IL2R 分子に対するモノクローナル抗体が, 拒絶反応の治 療薬として，有効であるかが, 動物実験16)20) 24)43) から 臨床レベル2526)44) 46)にまで広く検討されている。

Tilney らのグループは21130)，ラット心移植モデルを つかって, 拒絶反応時の活性化指標, 寸なわち, IL-2R 陽性細胞がみられること，MHCクラス II 抗原が細胞 膜上に検出されること，そして，活性化マクロファー ジが存在すること，を明らかにした。対照として，サ イクロスポリンの投与をらけた，拒絶反応のみられな い移植心や，免度遺伝学的に同系な移植心，それらの 漫潤細胞中には，活性化指標はごくわずかにしかみら れない，一方，移植前にドナーからの輸血などの前処 置をらけ, enhancement 状態にある生着中の移植心浸 潤細胞中には，活性化指標をもつ細胞が，未処置群の 急性拒絶反応時のときと量的に同程度に認められる。
この enhancement 状態にある移植心は, サプレッ サー細胞や抗イディタイプ抗体などの細胞性・液性の 抑制因子によって，拒絶反応からまぬがれていると考 えられているが29), enhancement 時にも，これら活性

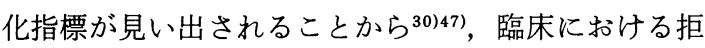
絶反応時の免疫学的活性化指標をとりあげる際には, 慎重な検討が必要となるであろう。

腎移植臨床における免疫学的モニタリングの手段と して，拒絶反応時の腎生検による組織採取，移植腎か らの吸引生検法による細胞採取 (Fine Needle Aspiration Biopsy, FNAB), そして, 尿中の細胞採取があ る. 臨床の場合, 動物実験と異なり, 腎生検の施行時 期が必らずしも一定せず，また，種々の免疫抑制療法 が施行されているため, 移植腎浸潤細胞の結果からひ とつの結論を導くのは容易ではない。さらに, ウイル 不感染症を合併していると, 拒絶反応だけの病態を把 むことが困難となる. Raffery ら ${ }^{48}$ は，移植後 1 週間以 内に計画的に実施した腎生検を行ない，活性化指標の らち, 活性化マクロファージの浸潤が拒絶反応例に著 明であり, MHC クラスII抗原の表現は拒絶反応に特 有ではない（IL-2R 陽性細胞については未検討である が）結果を報告している。活性化マクロファージと拒 絶反応とが関係する事象(2136) 38), 最近でも単球・マ クロファージに対する種々の新しいモノクローナル抗 体を用いた検討によって, 裏付けされている49) 51). 単 球・マクロファージが拒絶反応となんらかの関わりを もち，拒絶反応にとっても重要な免疫担当細胞である ことは認識されているが, ェフェクター機能としての 単球・活性化マクロファージの免疫応答を試験管内レ ベルにおいて知る方法がないため, 移植免疫反応にお ける活性化マクロファージの意味ずけがあいまいと なっている。この点について, 著者は, 新しい単球エ スェクターとして spontaneous plaque-forming cell (SPFC) 単球を見い出した ${ }^{52)}$. SPFCは, ヒト赤血球 抗原を認識し溶血する細胞性ェフェクターであり, 溶 血機序として SPFC 単球からの補体, oxygen radicals の分泌が考兄られている. SPFC 単球の産生は, T 細 胞や単球の調節性細胞によって, 制御をうけている。 SPFC 陽性単球は, たかだか全単球のうちの $7 \%$ 以下 の比率しかない。そして, 同種移植免度反応の試験管 内モデルとして, 受者と提供者間に拀いて, 両者の, 単球をふくむ，末梢単核球分画の混合培養によって, 提供者に対する $\mathrm{SPFC}$ 陽性単球の産生の程度を知る ことができる，すなわち，MLC-SPFC assay を確立し 
た.この SPFC 単球の発見により, 今後, 移植免疫反 応に招ける,ェフェクターとしての単球・マクロファー ジ系の意義が明らかにされていくものと考えてい $ろ^{53)}$. 拒絶反応時における浸潤細胞中の $\mathrm{T}$ 細胞の意義 は, $\mathrm{CD} 4 / \mathrm{CD} 8$ 比に関係はなく, むしろ $\mathrm{T}$ 細胞数の絶対 的な数の増加にある ${ }^{48154)}$. FNABによっても, IL-2R 陽性細胞, 活性化マクロファージ, 活性化 $\mathrm{T}$ 細胞の活 性化指標が有用であることが示されている55) 57). 尿中 の腎由来細胞や免疫担当細胞を採取し, 免疫組織学的

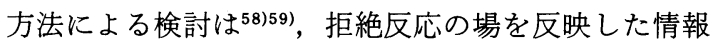
を得ることができ，有力な免度学的モニタリングとな る可能性がある。

\section{モノクローナル抗体と免疫抑制}

1981年 Cosimi ${ }^{2}$ によって, 急性拒絶反応の治療薬と して, OKT3, マウス IgG2a 抗ヒト CD3モノクローナ ル抗体が初めて臨床応用され, 有効性が認められ広く 臨床使用されるようになっている3)。このモノクロー ナル抗体 (monoclonal antibody, 以下 $\mathrm{mAb}$ と略す) の in vivo 投与により，マウス・ラットに拈ける拒絶反 応機序の研究に新しい方法論が導入され(14)15)17) 199, 拒 絶反応に関わる免疫担当細胞を同定することが可能と なった。これまで，拒絶反応を誘導する $\mathrm{T}$ 細胞集団を 同定するためには，マウス拉よびラットを用い，胸腺 摘出, $\mathrm{X}$ 線全身照射の後に, $\mathrm{T}$ 細胞集団を除去した骨 髄細胞を移入した“B”マウス又は“B”ラットを作成し た後しらべたい T 細胞を移入し拒絶反応を惹起する ことができるかによって，検討する方法が用いられて いた ${ }^{60) 61)}$. “B”動物作成とは異なり，移植前に標的とす る $\mathrm{T}$ 細胞に対する $\mathrm{mAb}$ を投与し, その結果として, 移植臓器の生着延長と末梢血中の標的細胞の陰性化を
指標にしながら，拒絶反応に関わる細胞集団を検討し

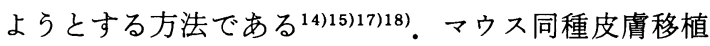
時に，抗 CD4（抗 L3T4）か抗 CD8（抗 Lyt-2） mAb を投与した時,クラス I 抗原不適合間移植では CD8陽 性 T 細胞を標的にした $\mathrm{mAb}$ が有効で拒絶反応抑制 効果を示し,クラス II 抗原不適合では CD4陽性 T 細胞 と反応する $\mathrm{mAb}$ が効果を示すが，いずれの場合も単 独より抗 $\mathrm{CD} 4$ と抗 $\mathrm{CD} 8 \mathrm{mAb}$ を同時に投与した時が

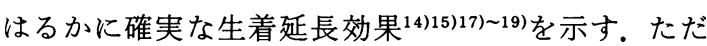
し, この実験モデルでは, minor H-2抗原の違いによる 比較的弱い組織不適合間の組合わせに括いて，CD4, $\mathrm{CD} 8$ に対する $\mathrm{mAb}$ が有効であり，強い $\mathrm{H}-2$ 不適合間 の場合は, mAbより, ATG(antithymocyte globulin) のポリクローナル抗体が有効である ${ }^{62) 63)}$. 拒絶反応時 の活性化指標のうち, IL-2R 陽性細胞に着目し, IL-2R に対する $\mathrm{mAb} の$ in vivo 投与による免度抑制効果の 研究が, マウス ${ }^{16) 19)}$, ラット ${ }^{2122)}$, primate ${ }^{23)}$ のなら ず,臨床に执いて 25)26)44)，なされている. IL-2R に対す る $\mathrm{mAb} と し て, \alpha$-chain, $\beta$-chain そして, 双方共通 の epitope に対する mAb があるが, どの epitope に対 する $\mathrm{mAb}$ が拒絶反応の抑制に有効かが検討されてい る.ラットに打いては, $\beta$-chain に対する $\mathrm{mAb} と \alpha$-と $\beta$-chain に共通な $\mathrm{mAb}$ が有効である ${ }^{2143)}$. IL-2R に対 する $\mathrm{mAb}$ の抑制効果の実験も，弱い組織不適合間の 組合わせでなされている。

OKT3が初めて臨床応用されて以来, OKT3がすぐ れた急性拒絶反応抑制効果をもつことは，すでに明ら かとなっている. OKT3の急性拒絶反応に対する寛解 率は約 $90 \%$ である ${ }^{3) 64)}$. OKT3導入以来, 表に示すよう ないろいろな種類の $\mathrm{mAb}$ が臨床に応用されている。

Table 1 Monoclonal antibodies under clinical evaluation except OKT3.

\begin{tabular}{|c|c|c|c|c|c|c|c|}
\hline \multirow{2}{*}{$\begin{array}{c}\text { Name } \\
\text { of } \\
\text { monoclonal } \\
\text { antibody }\end{array}$} & \multirow{2}{*}{$\begin{array}{l}\text { Origin } \\
\text { of } \\
\text { animal }\end{array}$} & \multirow{2}{*}{ Isotype } & \multirow{2}{*}{ Specificity } & \multirow{2}{*}{$\begin{array}{l}\text { Clinical } \\
\text { dose } \\
\text { (iv) }\end{array}$} & \multicolumn{2}{|c|}{$\begin{array}{c}\text { Clinical efficacy } \\
\text { on }\end{array}$} & \multirow{2}{*}{ References } \\
\hline & & & & & $\begin{array}{l}\text { rejection } \\
\text { therapy }\end{array}$ & $\begin{array}{c}\text { prophylaxis } \\
\text { therapy }\end{array}$ & \\
\hline Orthoclone OKT $3^{\circledR}$ & murine & IgG2a & CD3 & $5 \mathrm{mg} / \mathrm{d}$ & \# & + & (3) (64) (74) \\
\hline BMA 031 & murine & IgG2b & $\alpha / \beta-\mathrm{TCR}$ & $5-50 \mathrm{mg} / \mathrm{d}$ & + & \pm & $(66)(67)$ \\
\hline $\mathrm{T}_{10} \mathrm{~B}_{9} \cdot 1 \mathrm{~A}-31 \mathrm{~A}$ & murine & $\operatorname{IgMK}$ & CD3/TCR & $6 \mathrm{mg} / \mathrm{d}$ & $\pm \sim+$ & n.d. & (68) \\
\hline RIV9 & murine & IgG3 & CD3 & $5 \mathrm{mg} / \mathrm{d}$ & + & n.d. & (65) \\
\hline Leu $2 a$ & murine & IgG2a & CD8 & $10 \mathrm{mg} / \mathrm{d}$ & $\pm \sim+$ & n.d. & (73) \\
\hline $33 \mathrm{~B} 3 \cdot 1$ & rat & IgG1 & $\beta$-chain & $10-20 \mathrm{mg} / \mathrm{d}$ & - & + & (25) (24) \\
\hline & & & IL-2R & & & & (45) (46) \\
\hline anti-Tac & murine & IgG2a & $\begin{array}{l}\beta \text {-chain } \\
\text { IL-2R }\end{array}$ & $20 \mathrm{mg} / \mathrm{d}$ & n.d. & + & (26) \\
\hline
\end{tabular}

TCR : T cell receptor n.d. : not done 
OKT3のほかに, CD3に対する mAbでも isotype の異 なるもの ${ }^{65)}$, $\mathrm{T}$ 細胞レセプター( $\mathrm{T}$ cell receptor, $\mathrm{TcR}$ )

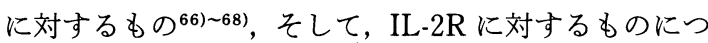
いて，急性拒絶反応に対する抑制効果と移植と同時の 投与による急性拒絶反応発症に対する予防効果につい て検討がなされている2526)44) 46). OKT3の臨床上の課 題として, 第 1 に, OKT3によっても制御しえない急性 拒絶反応例の存在 ${ }^{3)}$, 第 2 に, OKT3投与後に高頻度に 発症する CMV 感染症6970), 第 3 に, OKT3投与後の抗

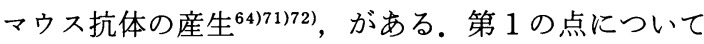
は，新たな免度抑制剂の出現を期待するしか方策はな い. 第 3 の点に関して, OKT3投与後の抗マウス抗体陽 性率は約30 50\% ${ }^{3(64) 71)}$ であり，抗体陽性率も OKT3 投与中の免疫抑制法にも依存する ${ }^{71}$. 抗マウス抗体陽 性例への OKT3の再投与は, 効果が減弱する点か $ら^{71)}$, 異なる isotype の mAb あるいは異なる特異性を 示す $\mathrm{mAb}$ で再投与に対しては適応となるだろう。現 在，臨床治験中 (欧米にて)にある $\mathrm{mAb}$ がすぐれた免 疫抑制効果を有すものがみつかれば，新たな免疫抑制 剂の展望を開くものになるだろう，BMAO3166667)は， $\mathrm{TcR}$ の public determinant に対する $\mathrm{mAb}$ であり，西 独を中心に臨床治験がなされ，拒絶反応の治療と予防 の両方に効果が認められている. IL-2R に対する $\mathrm{mAb}$ としては， $\beta$-chain に対する $\mathrm{mAb}$ が使用されている が25)26)，急性拒絶反応発症の予防効果はあるもの の ${ }^{25) 45)}$ ，急性拒絶反応時の治療効果はない(46). $\mathrm{T}_{10} \mathrm{~B}_{9}$ ・ $1 \mathrm{~A}-31 \mathrm{~A}^{68}$ は, CD3b と TcR の両方と反応する $\mathrm{mAb}$ で あり，OKT3より速効性で副作用が軽いといわれてい る. $\mathrm{CD} 8$ に対する $\mathrm{mAb}$ の急性拒絶反応抑制効果は OKT3より弱いが認められる ${ }^{73)}$. mAb と抗胸腺, 抗り ンパ球グロブリンなどのポリクローナル抗体との抑制 効果の比較については, $\mathrm{mAb}$ の方がポリクローナル抗 体より，急性拒絶反応時の治療効果そして予防投与に よる急性拒絶反応抑制効果いずれに打いて，無作為下 になされた臨床研究によって64774), すぐれていること が示されている。もちろん，mAbの単独投与による免 疫抑制導入によって, 急性拒絶反応の発症を予防する ことは不可能である ${ }^{75)}$. 多くの $\mathrm{mAb}$ が臨床応用され ようとしているが，このような臨床の試みは，一方に おいて，拒絶に関わる免疫担当細胞を明らかにしらる 点で意義をもち, 今後とも臨床研究面での展開が続く であろう。

OKT3使用上の課題として, OKT3投与後に CMV 感染症を高頻度に抗こし, 混合感染による致死的な重
症感染症になることがある。腎移植の場合は，心臓・ 肝臓の移植と違って，拒絶反応のため移植腎機能が機 能廃絶しても, 血液浄化法による社会復帰が可能であ るので，いわゆる過䛢免疫抑制による重症感染症から の死亡は避けなければならない，OKT3投与による感 染症を抑えるには基礎免疫抑制法が大きく影響すると いわれている69)。ヒト CMV は, 初感染後は白血球や腎 尿細管上皮内に潜伏感染として存在する. 臟器移植に 扣ける CMV 再活性化や初感染を促進する因子とし て, 第 1 亿, 宿主対移植片反応や移植片対宿主反応の 移植免疫反応それ自身 ${ }^{788)}$ ，第 2 に，免疫抑制剂の直接 作用，が挙げられる ${ }^{910)}$. 第 2 の点についての最近の 我々の研究では ${ }^{10)}$, 通常の臨床での薬剤血中濃度レべ ルと同じ薬剤濃度を用いた試験管内に打ける CMV 増 殖への免度抑制剂の作用を検討したところ，プレドニ ゾロンがもっとも強い CMV 増殖・感染促進作用を示 し, 次いでサイクロスポリンも促進作用を有す。ミジ リビンとアザチオプリンは，逆に CMV 増殖・感染へ の抑制作用をもち，サイクロスポリンとプレドニゾロ ンを併用した場合にみられる CMV 増殖に対しても, ともに抑制を示す。 OKT3の効果を最大に生かし副作 用を最小限にとどめるためには, 免疫抑制導入療法に おいて，可能な限り CMV の再活化性や初感染をひき おこしやすい薬剤一プレドニゾロン，サイクロスポリ ン, ALGなどを少量にて用い, 同時に, CMV 増殖に 抑制的に作用するブレデニンやアザチオプリンを併用 することが望ましい，藏器移植における CMV 感染の 制御については，抗ウイルス剂による制御も必要であ るが，長期的にみれば，CMV 感染にも重要と思われ る. ドナー・レシピエント間の拒絶反応の程度を決定 する組織適合性や新しい免废抑制剂もふくめた免疫抑 制剂の使用法をふくめた検討が必要であろう。

\section{サイクロスポリンの有効性と課題}

サイクロスポリンはすぐれた免疫抑制効果をもち， 蔵器移植免疫抑制療法の中心的薬剂である ${ }^{1)}$. 副作用 の腎毒性は投与量を減量することで，臨床上，許容さ れるものとなっている、サイクロスポリンの減量と同 時に，他の薬剤の使用が必要となり，そのためにさま ざまな多剤併用療法が工夫されている ${ }^{76)}$.わが国では, 独自に，ミゾリピンを併用した三剂併用療法がなされ ている ${ }^{7778)}$. いずれの方法によっても, 死体腎移植で 1 年生着率約80 90\%をえるが，先に述べたように，長 期にみると, 移植後 2,3 年後には $70 \%$ の生着率とな る4) 6).すなわち, サイクロスポリンによっても拒絶反 
応を制御しえない症例が存在するわけで，この点を明 らかにすることは，今後の免疫抑制療法を考学るらえ で重要となるであろら。最近，サイクロスポリンの試 験管内に打ける免疫担当細胞への抑制作用について, 抵抗性を示す症例があり，それら症例の予後がサイク ロスポリンに感受性を有す症例と比較して不良なこと が報告されている ${ }^{53) 79) 80)}$. 試験管内における $\mathrm{MLC}^{79)}$ たは $\mathrm{PHA}^{80}$ 試験にサイクロスポリンを添加した時 に, MLC またはPHA 反応を抑制できないサイクロス ポリン抵抗性を示す症例があり, 生着率は感受性を示 す症例に比して劣っている. 著者らも53), SPFC 単球の 産生系にサイクロスポリンを添加した時に, SPFC 単 球産生を抑制しえない症例があり, 抵抗性症例の生着 率は長期的にみて不良となっている。すなわち，サイ クロスポリン症例の慢性拒絶反応例に沶いて, サイク
ロスポリン抵抗性の免疫担当細胞が関わっている可能 性が示唆される.今後は，腎移植患者の予後を決定す る因子のなかに，免疫担当細胞の免疫担当細胞に対す る感受性という概念を導入する必要があり，これから の免疫抑制療法の課題となるであろら。

新しい免疫抑制剂の開発として，わが国から生みだ された FK506 ${ }^{81) 82)} と 15-d e o x y s p e r g u a l i n{ }^{83) 84) ~(15-~}$ DSG）がある．FK506は，T 細胞への免疫抑制効果の 点で, サイクロスポリンより100倍も強い抑制効果をも ち81), 米国にて pilot study がなされている。一方, 15-DSG は, $\mathrm{T}$ 細胞への抑制効果よりは単球・好中球系 への抑制活性をみとめる ${ }^{82)}$. 15-DSG は拒絶反応時の 抑制にすぐれた効果を示し，現在，わが国に打いて， 腎移植における急性拒絶反応の抑制効果を検討する初 期 II 相試験が実施され，急性拒絶に対する抑制効果が

表 2 腎移植一移植医療の推進のための社会的事業

\begin{tabular}{|c|c|}
\hline 日 & 大阪大学, 大阪府, 近畿の状況 \\
\hline 昭和 54 年 12 月 18 日 & $\begin{array}{l}\text { 「角膜及び腎臓の移植に関する法律」の制定と施行 } \\
\text { （遺族の承諾のもとに抢いて，死体からの腎臟摘出に関する死体損壊罪の違法性阻却） }\end{array}$ \\
\hline 昭和 55 年 6 月 6 日 & $\begin{array}{l}\text { 財団法人大阪腎臓バンクの設立 } \\
\text { （大阪府下に拈いて腎疾患の治療に関する学術研究を助成し, 腎不全患者に対し, 最善かつ充分な医療保護が } \\
\text { 加えられるょ5, 血液浄化法および腎移植に関する知識の啓発普及, 腎提供希望者および腎移植希望者の登録 } \\
\text { 等, 腎不全治療に関する必要な事業を行ない……福祉の向上に㟢与することを目的とする.） }\end{array}$ \\
\hline 昭和59年 6 月 14 日 & 脳死判定基準作成（大阪大学医学部脳死検討委員会） \\
\hline 昭和 60 年 10 月 24 日 & 大阪大学医学 \\
\hline 昭和 61 年 7 月 15 日 & $\begin{array}{l}\text { 大阪府腎移植推進連絡協議会発足 } \\
\text { (腎移植の普及を図るため大阪府下の医療機関及び大阪腎蔵バンクと連携し，提供腎の確保と円滑な死体腎移 } \\
\text { 植の指進に寄与することを目的とする） }\end{array}$ \\
\hline 昭和 62 年 2 月 12 日 & $\begin{array}{l}\text { 大阪大学医学部附属病院脳死判定に関する委員会設置 } \\
\text { (本院における脳死の判定を適正に行うことを目的とする) }\end{array}$ \\
\hline 昭和 62 年 4 月 23 日 & $\begin{array}{l}\text { 大阪大学医学部附属病院脳死判定実施要網制定 } \\
\text { (脳死判定の基準及び実施上の必要な事項について定める) }\end{array}$ \\
\hline 昭和63年 1 月 20 日 & $\begin{array}{l}\text { 大阪大学医学部倫理委員会に対し, 脳死の葴器提供者から適応患者への心・肝・腎移植を第一外科, 第二外科, } \\
\text { 泌尿器科から申請 }\end{array}$ \\
\hline 平成元年 2 月 17 日 & $\begin{array}{l}\text { 大阪府腎移植施設会議発足 } \\
\text { (大阪府下に拈ける腎移植(死体腎移植)を円滑に推進するため, 腎移植実施医療機関相互の連携を図るととも } \\
\text { に, 腎移植実施に関する指針を定め, もって大阪府腎移植ローカルエリア・ネットワークの構築を図ることを } \\
\text { 目的とする) }\end{array}$ \\
\hline 平成元年 3 月 17 日 & $\begin{array}{l}\text { 近畿地区腎移植推進協議会発足 } \\
\text { （近畿地区地方腎移植センター(兵庫県立西宮病院内) と近畿 } 4 \text { 府県(大阪，兵庫，奈良，和歌山)の医療機関及 } \\
\text { び行政機関等が十分な連携と調整を行い，当該地域の腎移植の円滑な推進を図ることを目的とする） }\end{array}$ \\
\hline 平成元年 4 月 4 日 & 大阪大学医学部倫理委員会が心・肝・腎移植の申請に対し中間勧告 \\
\hline 平成元年 8 月 20 日 & $\begin{array}{l}\text { 大阪大学医学部附属病院移埴医療連絡委員会設置 } \\
\text { （本院における移植医療に関連した諸問題を検討することを目的とする） }\end{array}$ \\
\hline 平成元年 8 月 4 日 & $\begin{array}{l}\text { 近幾臓器移植連絡会議発足 } \\
\text { (近畿地区に打ける蔵器移植(心・肝・腎など)を円滑に推進するため各蔵器移植実施医療機関相互の連携と近 } \\
\text { 畿臟器移植ネットワークの構築を目的とする. 現在, 作業部会で具体的な作業を行っている) } \\
\text { 近畿脳死研究会発足（藏器移植を踏まえた脳死の研究を行う） }\end{array}$ \\
\hline
\end{tabular}


認められている。

\section{III. 移植医療としての腎移植}

第三者からの善意による臓器提供によってのみ可能 となる移植医療としての腎移植は，昭和 54 年に成立し た“角膜および腎臓移植に関する法律”以来10年が経 過して招り，わが国での普及が十分な段階にあるとは 言い難いが，徐々にではあるが，移植医療体制の医学 的・社会的条件の整備にともない，理解をえつつある と思われる。透析療法をうけている末期腎不全患者に とって，腎移植をらけ，健康をとりもどしたいとする 気持は，一方において脳死段階で感器提供を決意した 患者家族があるとすれば，医療側が慎重な配慮に裏づ けられた移植医療システムを構築することによって， 満たされるであろう。また，よりよい移植医療システ ムと腎移植の成果に対する社会的評価，と同時に，脳 外科・救命救急医療の治療過程に扣いて得られる信頼, これら医療側への信頼があれば，脳死段階の中にあっ て, 遺族が臟器提供を決意するための前提条件のひと つが成立するであろう，問題は，どのような移植医療 システムをつくるか，であり，同時に，システムを支 える医療スタッフの質である。腎移植に打ける移植医 療システムは, 脳死段階で施行される心臓・肝臓移植

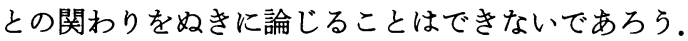
システムの運用面において，心蔵・肝臓移植との共通 点，相違点を現実にてらしあわせ，他領域の移植医間 との十分な検討を行ならことが必要である，移植医療 システムは，医学的・社会的諸事項からなる。医学的 には，最新の医学的実績に基づいた厳格な脳死判定基 準とその運用システムの存在（たとえば，脳死判定委 員会とその運用細則が確立していること), 移植医療に 拈いては相対的に提供者数と受者数との不均衡は不可 避であるため，医学的成果に立脚した公正な受者の選 択基準，とそれに基ついいた受者の登録システムや移植 施設の決定方法の確立, 藏器提供医療施設と移植医療 施設間における臟器提供の情報伝達之藏器摘出術の相 互の理解，および，心臓・肝臓移植医療施設間との連 絡会議の設立，などがある，社会的には，脳死を個体 死とした時の死亡時刻の確認方法, 監察医務医制度と 脳死段階での臟器提出の医学的・法的運用の検討, 脳 死段階での藏器摘出の医療費支払いの方法, 臓器移植 を支える財政的基盤としての財団法人の腎臓バンクと 行政間との調整，などがある．現在，脳死段階での移 植を行ならことを目的として，大学の倫理委員会への 申請がなされているが，このような積極的な動きに
よって，移植医療システムの確立に心要な，現実的な 医学的・社会的諸事項が検討され, 整備・構築されて いくであろう，今後, 腎移植にたずさわる移植医が中 心となり，多臓器移植をふくめた移植医療システムを 創りあべていく必要がある。この際，とくに対象臟器 が腎臓である点から，泌尿器科医の果すべき役割はま すます重大となることを忘れてはならない.おわりに， 表に，大阪，近畿地区に执いてこれまですすめられて きている移植医療システムについての経違と最近の動 きを示す。

\section{文 献}

1) European Multicentre Trial Group : Cyclosporin in cadavaric renal transplantation: One-year follow-up of a multicentre trial. Lancet, ii, 986-989, 1983.

2) Cosimi, A.B., Colvin, R.B., Burton, R.C., Rubin, R.H., Goldstein, G., Kung, P.C., Hansen, W.P., Delmonico, F.L. and Russel, P.S.: Use of monoclonal antibodies to T-cell subsets for immunologic monitoring and treatment in recipients of renal allografts. New Eng. J. Med., 305, 308-314, 1981.

3) Ortho Multicenter Transplant Study Group: A randomized clinical trial of OKT 3 monoclonal antibody for acute rejection of cadaveric renal transplantation. New Eng. J. Med., 313, 337-342, 1985.

4) Terasaki, P.I., Mickey, M.R., Cecka, M., Cicciarelli, J., Cook, D., Iwaki, Y., Toyotome, A. and Wang, L.: Overview. in Clinical Transplants, ed. by Terasaki, P.I., 467-490, Los Angeles, UCLA Tissue Typing Laboratory, 1987.

5）日本移植学会：堅移植臨床登録集計報告（1988 年). 移植, 24, 409-422, 1989.

6) Land, W.: Kidney transplantation-State of the art. Transplant. Proc., 21, 1425-1429, 1989.

7) Ho, M., Dowling, J.N. and Armstrong, J.A.: Factors contributing to the risk of CMV infection in patients receiving renal transplants. Yale J. Biol. Med., 49, 17-26, 1976.

8) Dowling, J.N.: Enhancement of HCMV infection during GVH reaction. J. Infect. Dis., 135, 990-994, 1977.

9) Dowling, J.N., Saslow, A.R., Armstrong, J.A. and Ho, M. : CMV infection in patients receiving immunosuppressive therapy for rheumatologic diseases. J. Infect. Dis., 133, 399-408, 1976.

10) Shirakii, K., Ishibashi, M., Okuno, T., Kokado, 
Y., Takahara, S., Tamanishi, K., Sonoda, T. and Takahashi, M.: Effects of cyclosporine, azathioprine, mizoribine, and prednisolone on replication of human cytomegalovirus. Transplant. Proc., (in press) 1990.

11) Simmons, R.L., Lopes, C., Balfour, H. Jr., Kalis, J., Rattazzi, L.C. and Najarian, J.S. : Cytomegalovirus: Clinical virological correlations in renal transplant recipients. Ann. Surg., 180, 623-634, 1974.

12) Peterson, P.K., Balfour, H.H. Jr., Marker, S.C., Fryd, D.S., Howard, R.J. and Simmons, R.L.: Cytomegalovirus disease in renal allograft recipients: A prospective study of the clinical features, risk factors and impact on renal transplantation. Medicine, 59, 283-300, 1980.

13) Tilney, N.L. and Kupiec-Weglinski, J.W.: Advances in the understanding of rejection mechanisms. Transplant. Proc., 21, 10-13, 1989.

14) Benjamin, R.J. and Waldmann, H.: Induction of tolerance by monoclonal antibody therapy. Nature, 320, 449-451, 1986.

15) Gutstein, N.L., Seaman, W.E., Scott, J.E. and Wofsy, D.: Induction of immune tolerance by administration of monoclonal antibody to L3T4. J. Immunol., 137, 1127-1132, 1986.

16) Kirkman, R.L., Barrett, L.V., Gaulton, G.N., Kelley, V.E., Ythiel, A.Z. and Strom, T.B.: Administration of an anti-interleuken 2 receptor monoclonal antibody prolongs cardiac allograft survival in mice. J. Exp. Med., 162, 358-362, 1985.

17) Ichikawa, T., Nakayama, E., Uenaka, A., Monden, M. and Mori, T.: Effector cells in allelic $\mathrm{H}-2$ class I-incompatible skin graft rejection. J. Exp. Med., 166, 982-990, 1987.

18) Sharabi, Y. and Sachs, D.H.: Engraftment of allogeneic bone marrow following administration of anti-T cell monoclonal antibodies and low-dose irradiation. Transplant. Proc., 21, 233-235, 1969.

19) Smith, D.M., McKisic, M., Stuart, F.P. and Fitch, F.W.: T-lymphocyte subsets: Major histocompatibility antigens rejection of $\mathrm{H}-2 \mathrm{~K}$ or $\mathrm{H}$-2I region disparate skin allografts by either Lyt $-2^{+}$or $\mathrm{L} 3 \mathrm{~T} 4^{+}$T-lymphocyte subset. Transplant. Proc., 21, 162-164, 1989.

20) Kirkman, R.L., Barrett, L.V., Koltum, W.A. and Diamanstein, T.: Prolongation of murine cardiac allograft survival by the antiinterleuken-2 receptor monoclonal antibody AMT-13. Trans- plant. Proc., 19, 618-619, 1987.

21) Hancock, W.W., Lord, R.H., Colby, A.J., Diamanstein, T., Rickles, F.R., Diskstora, C., Hogg, N.Z. and Tilney, N.L. : Identification of I1-2R ${ }^{+} T$ cells and macrophages within rejecting rat cardiac allografts, and comparison of the effects of treatment with anti-IL-2R monoclonal antibody or cyclosporine. J. Immunol., 138, 164-170, 1987.

22) Kupiec-Weglinski, J.W., van der Meide, P., Stunkel, K.G., Tanaka, K., Diamanstein, T. and Tilney, N.L.: Interleuken 2 receptor directed therapy in rat recipients of cardiac allografts: Synergistic and antagonistic intractions with the gamma interferon network. Transplant. Proc., 21, 992-993, 1989.

23) Shapiro, M.E., Kirkman, R.L., Read, M.H., Puskas, J.D., Mazoujian, G., Letvin, N.L., Carpenter, C.B., Milford, E.L., Waldmann, T.A., Strom, T.B. and Sclossman, S.F.: Monoclonal anti-IL-2 receptor antibody in primate renal transplantation. Transplant. Proc., 19, 594 $-598,1987$.

24) Friend, P.J., Calne, R.Y., Hale, G., Waldmann, H., Evans, D.B., Rolles, K., Thiru, S. and Gore, S.: Prophylactic use of an antilymphocyte monoclonal antibody following renal transplantation: A randomized controlled trial. Transplant. Proc., 19, 1898-1900, 1987.

25) Soulillou, J.P., Peyronnet, P., LeMauff, B., Hourmant, M., Olive, D., Maeas, C., Delaage, M., Hirn, M. and Jacques, Y.: Prevention of rejection of kidney transplants by monoclonal antibody directed against interleuken 2 . Lancet, 1, 1339-1342, 1987.

26) Kirkman, R.L., Shapiro, M.E., Carpenter, C.B., Milford, E.L., Ramos, E.L., Tilney, N.L., Weldmann, T.A., Zimmerman, C.E. and Strom, T.B. : Early experience with anti-Tac in clinical transplantation. Transplant. Proc., 21, 1766 -1768, 1989.

27) Andrus, L. and Lafferety, K.J.: Inhibition of T-cell activity by cyclosporine A. Scand. J. Immunol., 15, 449-458, 1982.

28) Fabre, J.W. and Morris, P.J.: Passive enhancement of homozygous renal allografts in the rat. Transplantation, 18, 428-435, 1974.

29) Davies, D.A.L. : Enhancement. in Transplantation Immunology Clinical and Experimental. Edited by Calne, R.Y. p. 208-221, Oxford University Press, 1984.

30) Lord, R.H.H., Padberg, W.M., Hancock, W.W., 
Kupiec-Weglinski, J.W. and Tilney, N.L.: Correlation of macrophage and NK cell numbers with "activation markers" in rat cardiac allografts. Transplant. Proc., 21, 449-450, 1989.

31) Uchiyama, T., Broder, S. and Waldmann, T.A. : A monoclonal antibody (anti-Tac) reactivity with activated and functionally mature human T cells. I. Production of anti-Tac monoclonal antibody and distribution of $\mathrm{Tac}(+)$ cells. J. Immunol., 126, 1393-1397, 1981.

32) Smith, K.A.: Interleuken 2. Annu. Rev. Immunol., 2, 319-333, 1984.

33) Waldmann, T.A.: The structure, function, and expression of interleuken-2 receptors on normal and malignant lymphocytes. Science, 232, 727-732, 1986.

34) Halloran, P.F., Wadgymar, A. and Antenried, P.: The regulation of expression of major histocompatibility complex products. Transplantation, 41, 413-420, 1986.

35) Harris, H.W. and Gill, T.J. III. : Expression of class I transplantation antigens. Transplantation, 42, 109-117, 1986.

36) Häyry, P., von Willebrand, E., Parthenais, E., Nemlander, A., Soots, A., Lautenschlager, I., Alfoldy, P. and Renkonen, R.: The inflammatory mechanisms of allograft rejection. Immunol. Res., 77, 85-142, 1984.

37) MacPherson, G.G. and Christmas, S.E.: The role of the macrophage in cardiac allograft rejection in the rat. Immunol. Rev., 77, 143 $-166,1984$.

38) Mason, D.W., Dallman, M.J., Arthur, R.P. and Morris, P.J.: Mechanisms of allograft rejection: The roles of cytotoxic T-cells and delayed-type hypersensitivity. Immunol. Rev., 77, 167-184, 1984.

39) Lowry, R.P., Magghesco, D.M. and Blackburn, J.H.: Immune mechanisms in organ allograft rejection. IV. Delayed-type hypersensitivity and lymphotoxin in experimental renal allograft rejection. Transplantation, 40, 183-188, 1985.

40) Halloran, P.F., Cockfield, S.M. and Madrenas, $\mathrm{J}$.: The mediators of inflammation (interleukin 1 , interferon- $\gamma$, and tumor necrosis factor) and their relevance to rejection. Transplant. Proc., 21, 26-30, 1989.

41) Maury, C.P.J. and Teppo A-M. : Raised serum levels of cachectin/tumor necrosis factor $\alpha$ in renal allograft rejection. J. Exp. Med., 166, 1132 $-1137,1987$.
42) Sharon, M., Klausner, R.D., Cullen, B.R., Chizzonite, R. and Jeonard, W.J.: Novel interleuken-2 receptor subunit detected by cross-linking under high-affinity conditions. Science, 234, 859-863, 1986.

43) Tellides, G., Dallman, M.J. and Morris, P.J. : Mechanism of action of interleuken-2 receptor (IL-2R) monoclonal antibody (MAb) therapy : Target cell depletion or inhibition of function? Transplant. Proc., 21, 997-998, 1989.

44) Cantarovich, D., Le Mauff, B., Hourmant, M., Peyronnect, P., Jacques, Y., Boeffard, F., Hirn, M. and Soulillou, J.P.: Prophylactic use of a monoclonal antibody (33B3. 1) directed against interleuken 2 receptor following human renal transplantation. Am. Kidney Dis., 11, 101-106, 1988.

45) Cantarovich, D., Le Mauff, B., Hourmant, M., Giral, M., Denis, M., Jacques, Y. and Souliillou, J.P.: Anti-IL2 receptor monoclonal antibody (33B3. 1) in prophylaxis of early kidney rejection in humans: A randomized trial versus rabbit antithymocyte globulin. Transplant. Proc., 21, 1769-1771, 1989.

46) Cantarovich, D., Le Mauff, B., Hourmant, M., Giral, M., Denis, M., Hiru, M., Jacques, Y. and Soulillou, J.P.: Treatment of acute kidney rejection episodes with monoclonal antibody directed against IL2 receptor: A pilot study. Transplant. Proc., 21, 1785-1786, 1989.

47) Dallman, M.J., Wood, K.J. and Morris, P.J.: Specific cytotoxic $T$ cells and found in the nonrejected kidneys of blood-transfused rats. J. Exp. Med., 165, 566-571, 1987.

48) Raftery, M.J., Seron, D., Hartley, B., Koffman, G. and Cameron, J.S.: Immunohistological analysis of the early renal allograft biopsy. Transplant. Proc., 21, 280-281, 1989.

49) Bogman, M.J.J.T., Dooper, M.M., Assman, K.J. M., Van de Winkel, J.G.J., Tax, W.J.M., Maass, C.N. and Koene, R.A.P.: Immunohistologic staining of renal transplant biopsies with monoclonal antibody WT14: A new parameter for the diagnosis of rejection. Transplant. Proc., 21, 1886-1887, 1989.

50) Gassel, A.M., Radzum, M.L., Hansman, H.-J., Weyand, M. and Konertz, W. : Monocytes and macrophages in the rejection of human cardiac allografts. Transplant. Proc., 21, 2514-2516, 1989.

51) Zappala, S.M., Khavli, R.B., Miller-Graziano, C., Takayama, T.K., Stoff, J.S. and Menon, M. : 
Evaluation of monocyte procoagulant activity as a parameter for immunologic monitoring in renal transplantation. Transplant. Proc., 21, 1844-1845, 1989.

52) Ishibashi, M., Kokado, T., Takahara, S. and Sonoda, T. : Cellular immune response against human red blood all antigens and renal allograft rejection. Transplant. Proc., 19, 4511 -4515, 1987.

53) Ishibashi, M., Jiang, H., Kokado, Y., Takahara, S. and Sonoda, T.: Immunopharmacologic effects of immunosuppressive agents explored by a new effector monocyte generation assay. Transplant. Proc., 21, 1854-1858, 1989.

54) MacWhinnie, D.L., Fuggle, S.V., Azevedo, L.S., Carler, N.P. and Morris, P.J. : Correlation of HLA class II antigen induction and cellular infiltration in renal allograft rejection. Transplant. Proc., 21 : 320-321, 1989.

55) Pfeffer, R.F., Gjertsen, H.A., Gaūdernack, G., Lexon, P.B., Sodal, G. and Thorsby, E. : Analysis of infiltrating lymphocytes from fine needle aspiration biopsies in kidney transplant patients by a rapid and sensitive immunomagnetic method. Transplant. Proc., 21, $354-355,1989$.

56) Helderman, J.H., Hernandez, J., Glennie, J. and Womble, D.: Analysis of the IL-2 receptor by monoclonal antibody of fine needle aspiration specimens. Transplant. Proc., 21, 3574-3575, 1989.

57) Cunningham, P.R.G., Gross, U., Matthews, C., Sash, C., Thomas, F. and Thomas, J. : Differential effects of immunosupressive agents on mononuclear cells infiltrating human renal allografts. Transplant. Proc., 21, 194-195, 1989.

58) Dooper, M.M.Ph., Bogman, M.J.J.T., Maass, C. N., Vooys, G.P. and Koene, R.A.P.: Immunocytology of urinary sediments in the diagnosis of rejection of renal allografts. Transplant. Proc., 21, 1873, 1989.

59) Segasothy, M., Birch, D.F., Fairley, K.F. and Kincaid-Smith, P.: Monoclonal antibody identification of nucleated cells in urine: Diagnosis of allograft rejection. Transplant. Proc., 21, 1878-1879, 1989.

60) Loveland, B.E. and McKenzie, I.F.C.: Cells mediating graft reject in the mouse. II. Ly phenotypes of cells producing tumor allograft rejection. Transplantation, 33, 174-180, 1982.

61) Loveland, B.E. and McKenzie, I.F.C.: Which
T-cells cause graft rejection? Transplantation, 33, 217-221, 1982.

62) Sherbourne, C.G. and Condie, R.M. : Immunosuppressive activity of monoclonal antiThy-1.2: Comparison of monoclonal IgM and IgG with xenoantithymocyte preparations. Transplant. Proc., 13, 504-508, 1981.

63) Sherburne, C.G., Cordie, R.M. and Onyekaba, C. O.: Basis for differing biological immunosupressive potencies of monoclonal and polyclonal T cell antibodies. Transplant. Proc., 21, 1036-1029, 1989.

64) Kreis, H., Chkoff, N., Chatenoud, L., Debure, A., Lacombe, M., Chrétien, Legendre, C., Caillat, S. and Boch, J.F. : A randomized trial comparing the efficacy of OKT3 used to prevent or to treat rejection. Transplant. Proc., 21, 1741-1744, 1989.

65) Vaessen, L.M.B., Kreeftenberg, J.G., Heyse, P., Leerling, M.F., Baumgartner, D., Hendriks, G.F. J., Jutte, N.H.P.M. and Weimeg, W.: RIV-9 : A mouse IgG3 anti-human CD3 monoclonal antibody with strong antigen modulating and $\mathrm{T}$ cell eliminating properties. Transplant. Proc., 21, 1026-1027, 1989.

66) Hillebrand, G., Rothaug, E., Hammer, C., Illner, W.D., Schleibner, St., Racenberg, J., Gurland, H. J. and Land, W.: Experience with a new monoclonal antibody in clinical kidney transplantation. Transplant. Proc., 21, 1776-1777, 1989.

67) Kurrle, R., Kanzy, E.J., Racenberg, J., Land, W. and Seiler, F.R.: BMA 031-A TCR-specific monoclonal antibody for clinical application. Transplant. Proc., 21, 1017-1019, 1989.

68) Waid, T.H., Lucas, B.A., Thompson, J.S., Brown, S., Moore, D., Amlot, P. and Janossy, G. : Treatment of acute cellular kidney allograft rejection with $\mathrm{T}_{10} \mathrm{~B}_{9} \cdot 1 \mathrm{~A}-31 \mathrm{~A}$ anti $\mathrm{T}$-cell monoclonal antibody. Transplant. Proc., 21, 1778-1784, 1989.

69) Munder, R., Hutchins, M., First, M.R., Carey, M., Schroeder, T. and Alexander, J.W. : Infection in OKT3-treated patients receiving addi. tional antirejection therapy. Transplant. Proc., 21, 1763-1765, 1989.

70) Bunchman, T.E., Nerins, T.E., Mauer, S.M. and Chavers, B.M. : Viral complications of OKT3 monoclonal antibody therapy in children undergoing renal transplantation. Transplant. Proc., 21, 1761-1762, 1989.

71) First, M.R., Schroeder, T.J., Hurtubise, P.E., 
Mansour, M.E., Penn, I., Munda, R., Balistreri, W.F., Alexander, J.W., Melvin, D.B., Fidler, J. P., Ryckman, F.C. and Brunson, M.E. : Immune monitoring during retreatment with OKT3. Transplant. Proc., 21, 1753-1754, 1989.

72) Hrick, D.H., Zarconi, J. and Schulak, J.A.: Concomitant low-dose cyclosporine and OKT3 therapy for renal transplant rejection. Transplant. Proc., 21, 1755-1757, 1989.

73) Wee, S.L., Phelan, J.M., Preffer, F.I., Colvin, R. B. and Cosimi, A.B.: Anti-Leu 2a (anti-CD8) monoclonal antibody therapy: Antibodymediated cell clearance in vivo requires FcFcRII interaction. Transplant. Proc., 21, 117-118, 1989.

74) Light, J.A., Khawand, N., Ali, A., Brems, W. and Aquino, A.: Comparison of Minnesota antilymphocyte globulin and OKT3 for induction of immunosuppression in renal transplant patients. Transplant. Proc., 21, 1738-1740, 1989.

75) Vigeral, P., Chkoff, N., Chatenoud, L., Campos, H., Lacombe, M., Droz, D., Goldstein, G., Bach, J.F. and Kreis, H. : Prophylactic use of OKT3 monoclonal antibody in cadaver kidney recipients. Utilization of OKT3 as the sole immunosuppressive agent. Transplantation, 41, 730-733, 1986.

76) Morris, P.J. : Single or multiple drug therapy. Transplant. Proc., 21, 820-822, 1989.

77) Kokado, Y., Ishibashi, M., Jiang, H., Takahara, S. and Sonoda, T.: A new triple-drug induction therapy with low dose cyclosporine, mizoribine and prednisolone in renal transplantation. Transplant. Proc., 21, 1575-1578, 1989.

78) Osakabe, T., Uchida, H., Masaki, Y., Yokota, K., Sato, K., Nakayama, Y., Ohkubo, M., Kumano, K., Endo, T., Watanabe, K. and Aso, K. : Studies on immunosuppression with low- dose cyclosporine combined with mizoribine in experimental and clinical cadaveric renal allotrans-plantation. Transplant. Proc., 19, 1958-1600, 1987.

79) Bowes, L.G., Dumble, L.J., Clunnie, G.J.A., Francis, D.M.A., Macdonald, I.M. and KincaidSmith, P. : Increased risk of rejection in renal transplant recipients with in vitro cyclosporinresistant lymphoid response. Transplant. Proc., 21, 1470-1471, 1989.

80) House, A.K., Potter, J.M., Pedersen, K.E., Kinnear, B.F. and Walker, K.B. : Immunosuppression failure: A function of lymphocyte steroid and cyclosporin resistance. Transplant. Proc., 21, 1573-1574, 1989.

81) Goto, T., Kino, T., Hatanaka, H., Nishiyama, M., Okuhara, M., Kohsaka, M., Aoki, H. and Imanaka, H. : Discovery of FK-506, a novel immunosuppressant isolated from Streptomyces Tsukubaensis. Transplant. Proc., 19 (Supple. 6) : 4-8, 1987.

82) Ochiai, T., Nakajima, K., Sakamoto, K., Nagata, M., Gunji, Y., Asano, T., Isono, K., Sakamaki, T. and Hamaguchi, K. : Comparative studies on the immunosuppressive activity of FK506, 15-deoxyspergualin, and cyclosporine. Transplant. Proc., 21, 829-832, 1989.

83) Nemoto, K., Hayashi, M., Abe, F., Nakamura, T., Ishizuka, M. and Umezawa, H. : Immunosuppressive activities of 15-deoxyspergualin in animals. J. Antibiotics, 40, 561-562, 1987.

84) Suzuki, S., Kanashiro, M. and Amemiya, H. : Effect of new immunosuppressant, 15deoxyspergualin, on heterotopic rat heart transplantation in comparison with cyslosporine. Transplantation, 44, 483-487, 1987. 